\title{
CALL-BASED INSTRUCTION MODEL OF SPEAKING ENGLISH (A Developmental Research at the English Language Education Study Program of STKIP Kusuma Negara, Jakarta)
}

\author{
Siti Yulidhar Harunasari*, Aceng Rahmat** \\ Kusuma Negara School of Teacher Training and Pedagogy, Indonesia* \\ FBS Universitas Negeri Jakarta, Indonesia** \\ yulidhar1@stkipkusumanegara.ac.id* \\ aceng57@gmail.com**
}

\begin{abstract}
The objective of this research is to develop a model of learning speaking English for students majoring in English Language Education in STKIP Kusuma Jakarta, and to examine the effectiveness of CALL-Based instruction the model in improving students' speaking skill. The research was conducted using system approach model of Dick and Carey, and was carried out from October 2012 to July 2014 in 3 stages i.e. preliminary stage; model development stage; validation, evaluation, and revision stage. The data were obtained through tests, questionnaires, interviews, observation, and expert judgments. The English speaking test was designed to measure students speaking skill before and after the implementation of the model. Then, the data were analyzed qualitatively and quantitatively. The research findings showed that the development of the model can improve the students' speaking skill through the increase in the mean score before the implementation of the model, 61 to 69 after implementation of the model. The testing of hypothesis using paired-samples t-test resulted in a probability value (sig) $0.000<\alpha=0.05$ which means that there is a significant difference on students speaking skill before and after implementing the CALL-based instruction model. It can be concluded that the model is effective in improving the students speaking skill in English Education Study Program of STKIP Kusuma Negara Jakarta.
\end{abstract}

Keywords: instruction model, English speaking skill, Computer Assisted Language Learning/CALL.

Innovations on Information and Communications Technology (ICT) have generated impacts on learning process. Along with the ease of accessing information and communications, learning process has been assisted, complemented with, and developed from the traditional classroom to the use of ICT such as the Internet and other web-based tools. In fact, ICT has also become one of the approaches in foreign language learning, ranging from the drill-and-practice to the Virtual Learning Environments (VLEs), and distance learning-based web applications.

Language learning involving the use of technological innovations is an interactive system between students and technology. In this research, computer, a widely-used technological innovation is chosen to assist the language learning. Often abbreviated and known as CALL, it describes the way computers used to assist and complement classroom instruction.

Thornbury defines CALL as one of a number of names to describe the way that computers are used to complement classroom instruction and is also an aspect of TELL (Technology-Enhanced Language Learning/TELL) (2006:42). Hartoyo defines Computer Assisted Language Learning/CALL as language learning involving the use of computers generally refers to the interactive computer system 
(hypertext /multimedia system) in which the student and the computer can interact, and students have the freedom to choose any topic or events they will learn (2008:21). Based on these definitions, it is understood that CALL is a more specific part of the Technology-Enhanced Language Learning.

The development of CALL has been started from the 1960s and firstly characterized by the drill-and-practice. It is the earliest CALL procedure termed as Behavioristic. It requires students to respond to the stimuli on a computer screen or to perform a variety of tasks such as filling in the blanks in a text, pairworks, multiple choice activities, listening, and drills. Then, computers will analyze input from students and then provide feedbacks. More complex CALL program are then designed to respond to students' mistakes made by connecting users (branching) to the help page and improvement activities.

The second stage of CALL development put more emphasis on the use of language than the language analysis. The softwares of CALL at this stage still provided an opportunity to practice the skills but not in the format of the drills. Some of these include reconstructing sentences and language games with the computer as a tutor. The computer provided a context for students to use language such as asking for directions and there are also programs that are not designed for language learning such as SimCity, but can also be used to learn the language.

The third stage is the Integrative CALL. It integrates learning language skills into learning tasks by providing directions and coherence. It is done through multimedia i.e. text, images, sounds and animation, and computer-based communication (Computer Mediated Communication/CMC), which then responded by users. CALL's procedure in this stage has shifted from firstly characterized by the drill-and-practice and tutorial to a system that facilitates the learning beyond the classroom. The shift also includes the use of programs that respond to oral and written inputs from users such as Intelligent CALL or CALL that uses artificial intelligence (Thornbury, 2008: 43). One simple example of artificial intelligence applied in learning English is English tutor robots that can be accessed on http://www.eslfast.com/robot/tutor_mike.htm. Users who are the English learners can communicate in written language with the English robot tutor that will respond to questions and correct users' errors in grammar and vocabulary in the immediate time or "real time". While for those who are at a higher level of proficiency, they can work with Elbot the Chatbot which can be accessed at http://www.elbot.com.

For English teachers/pre-service teachers, to master English is a form of professional competencies - one of the four competencies that must be possessed by teachers as stated in Law No.14 Year 2005 on Teachers and Lecturers. Besides English for teaching purposes, mastering English as the language of instruction must also be mastered. However, English speaking skills cannot be mastered easily in a short time because this skill requires more than being proficient in grammar and semantics. English speaking skills will be achieved through a learning process that needs a lot of practices and opportunities to speak in English.

The process of learning a language speaking skills would be more difficult if the language is not used daily. It is like learning English in Indonesia which is studied as a foreign language. Not only students are required to communicate effectively, but also to use the appropriate language in social interaction. This means that students should get a plenty of opportunities to practice English in real-life situations using suitable learning approach. 
Communicative approach is an approach emphasizing communication as its main goal. This approach facilitates students with a variety of techniques such as simulations, discussions and role plays. The techniques in this approach are designed to enable studentst o set up the purpose of communication.

Computer-Assisted Language Learning (CALL) facilitates students and teachers to easily access online learning resources that provides information and abundant learning resources on the Internet. CALL also provides language models and opportunities for students to be able to immediately use the new vocabulary or expressions acquired both from written and spoken language. Computer with multimedia applications complements activities and classroom interaction. In-site activities such as communicative practices can be the follow-up activities in learning language structures and vocabulary studied by utilizing hypertext technology. This prior self-learningare expected to build students' self confidence to practice speaking in classroom.

The result of the researcher's Master thesis conducted in English Language Education Study Program STKIP Kusuma Negara entitled "Improving English Speaking Skills through the Application of Role Play Techniques" indicates that through the Communicative Approach, students can improve their fluency. The study recommends that lecturers give extra attention to improving aspects of accuracy (Harunasari, 2011:143). In addition, since STKIP Kusuma Negara is a Teacher Education Program Provider (LPTK) that provides education for prospective teachers of English with one of its mission to prepare professionals in the field of Education, the researcher attempts to develop a learning model that not only provides opportunities for students to practice in real-life communication, but also necessitate linguistic knowledge to improve students English speaking skill. The learning model which is the result of the study is expected to cater the needs of students as well as to solve students' problems in mastering English speaking skill in STKIP Kusuma Negara.

This study focused on developing an instruction model to improve students' English speaking skill in English Language Education of STKIP Kusuma Negara, Jakarta. This research basically will reveal the following research problem: What is CALL-based instruction model to improve speaking skill of students in English Language Education of STKIP Kusuma Negara?

The research problem brings some following questions: 1) What are students' needs in learning English speaking skill; 2) How is English speaking learning in the English Language Education Study Program of STKIP Kusuma Negara; 3) How is CALL-based instruction model designed for students of English Education STKIP Kusuma Negara to learn speaking skill; (4) Based on experts' opinions, how is the feasibility of the CALL-based instruction model designed for students of English Education STKIP Kusuma Negara to learn speaking skill; (5) How is the effectiveness of the final CALL-based instruction model designed for students of English Education STKIP Kusuma Negara to learn speaking skill?

\section{METHOD}

The research method is developmental research. It was conducted from October 2012 until July 2014 in the English Language Education Study Program of 
STKIP Kusuma Negara Jakarta using the systematic approach model of Dick and Carey, and Gall and Borg (2003: 569). According to Gall and Borg's recommendations to limit the scale of the research project for the development of theses and dissertations only until a few stages of the cycle of research and development, and that according to Dick and Carey that the tenth step of an R \& D is not an integral part of the development process, and also based on the reason that the development of this model is intended to cater the needs of teaching learning process in STKIP Kusuma Negara, then the study was carried out only up to the ninth stages, namely revision of the final product.

The research procedure consisted of three main stages. They are preliminary stage; development stage; and the stage of validation, evaluation and model revision.

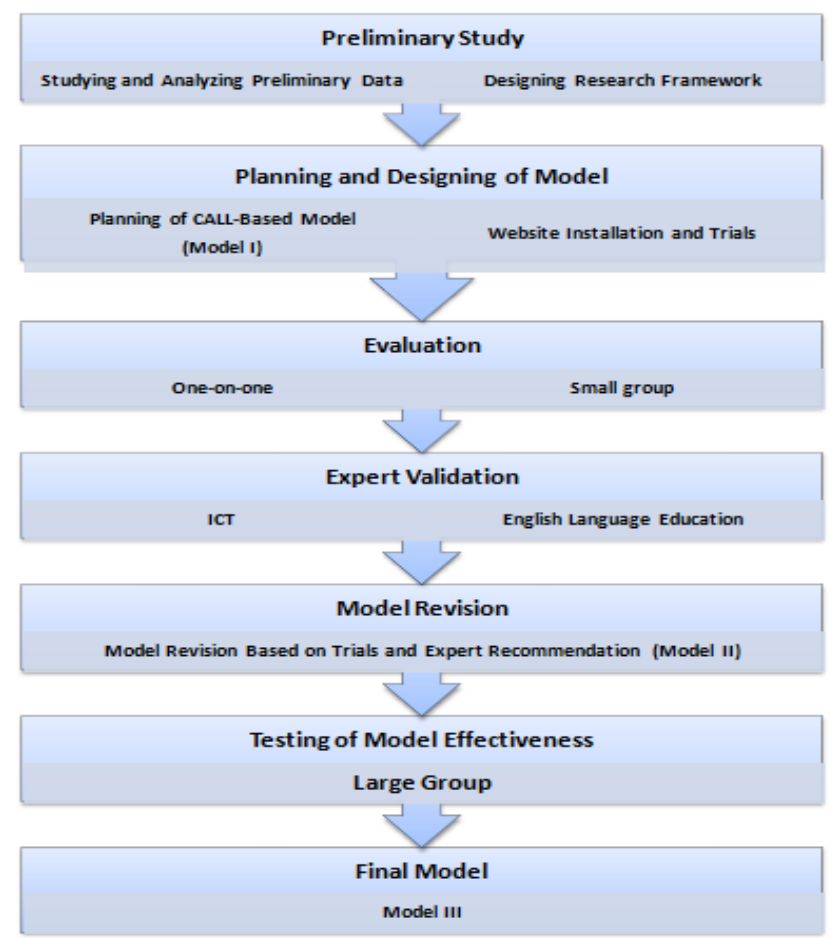

Figure 1. Research Development Stages

Research data were obtained through needs analysis, environmental analysis, interviews, and English speaking tests. The needs analysis was conducted using selfreport method to determine the learning needs of the speaking course participants. The analysis that measures aspects of necessities, lacks, and want was adapted from Nation and Macalister (2010: 24 -25). The data were then analyzed qualitatively by ways of tabulating and analyzing questionnaire answers, and make a report and recommendation (Richards, 2005: 64).

Evaluation stage was done in three steps, namely one-on-one evaluation, small group evaluation, and large group evaluation (Dick and Carey, 2005: 282-292). Validation to the model was obtained from ICT expert and English language education specialists through consultation and discussion forum. The model design then developed and revised after its feasibility examined through expert assessment guidelines. 
Testing of the model effectiveness was conducted through trials in large group using experimental method with one-group pretest-posttest design. The effect of treatment is determined by comparing pretest and posttest scores using pairedsamples t-test.

\section{RESULTS AND DISCUSSION}

\section{Preliminary Stage}

The preliminary stage produced a theoretical design of instructional model. A needs analysis to measure aspects of motivation, learning purpose, language function, information, and ICT was conducted to determine the general idea of the students' learning needs. The findings showed that students need more conversation practices, additional learning material about the language function, and conversation models by native speakers of English.

An environment analysis was also conducted utilizing interviews with lecturers and classroom observations. The observation results showed that: 1) the lecturers still dominate the conversation compare to students, 2) lecturers use more textbooks than multimedia, 3) lecturers used presentation method by giving specific topics to students and then have them prepared and presented the topics to the class, and 4) students are interested to daily topics of language function used everyday and to the use of technology in the classroom.

\section{Model Development Stage}

Model development stage and formative evaluation were conducted continuously so that during the development process Model I and Model II were produced after one-on-one evaluation and small group trial.

The first platform used for this model was Moodle. This Learning Management System (LMS) was located on http://yulidhar.stkipkusumanegara .ac.id. However, in the process of the development, there were several constraints, among others, the disappearance of the drop down menu that supposed to be the most important part of the learning model being developed. Another constraint was that some teachers feel the system to a certain extent was complicated for novice users, especially when they need to convert some files using Hotpotatoes software.

\section{Selamat Datang di Blended Learning You are not logged in. (Login}

Available Courses

\begin{tabular}{|c|c|c|c|c|c|c|}
\hline \multicolumn{7}{|c|}{ Calendar } \\
\hline 4 & \multicolumn{6}{|c|}{ October 2012} \\
\hline Sun & Mon & Tue & Wed & Thu & Fri & Sat \\
\hline & 1 & 2 & 3 & 4 & 5 & 6 \\
\hline 7 & 8 & 9 & 10 & 11 & 12 & 13 \\
\hline 14 & 15 & 16 & 17 & 18 & 19 & 20 \\
\hline 21 & 22 & 23 & 24 & 25 & 26 & 27 \\
\hline 28 & 29 & 30 & 31 & & & \\
\hline
\end{tabular}

Figure 1. Platform I 
The second platform which later on became a part of the model is a simple Learning Content Management System namely CMS Lokomedia which load speed is relatively higher compare to the previous platform. This LCMS can be accessed via a webpage accessible at STKIP Kusuma Negara on http://stkipkusumanegara.ac.id by clicking on the E-Learning tab, or directly on http://yulidhar1.stkipkusumanegara.ac.id/login.php for students, and on http://yulidhar1.stkipkusumanegara.ac.id/administrator/index.php for teachers and administrators.

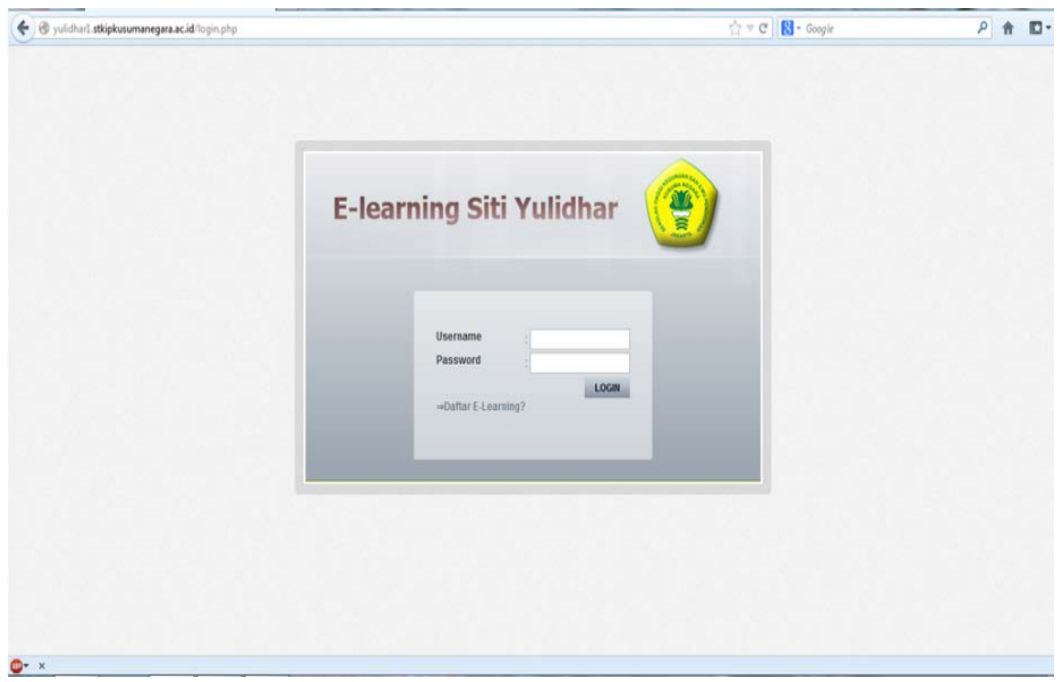

Figure 3. Platform II

\section{Validation, Evaluation, and Revision Stage}

Revisions to the CALL-based instruction model were based on feedback from experts' judgement to produce the final model (Model III) as can be seen in Figure 4.

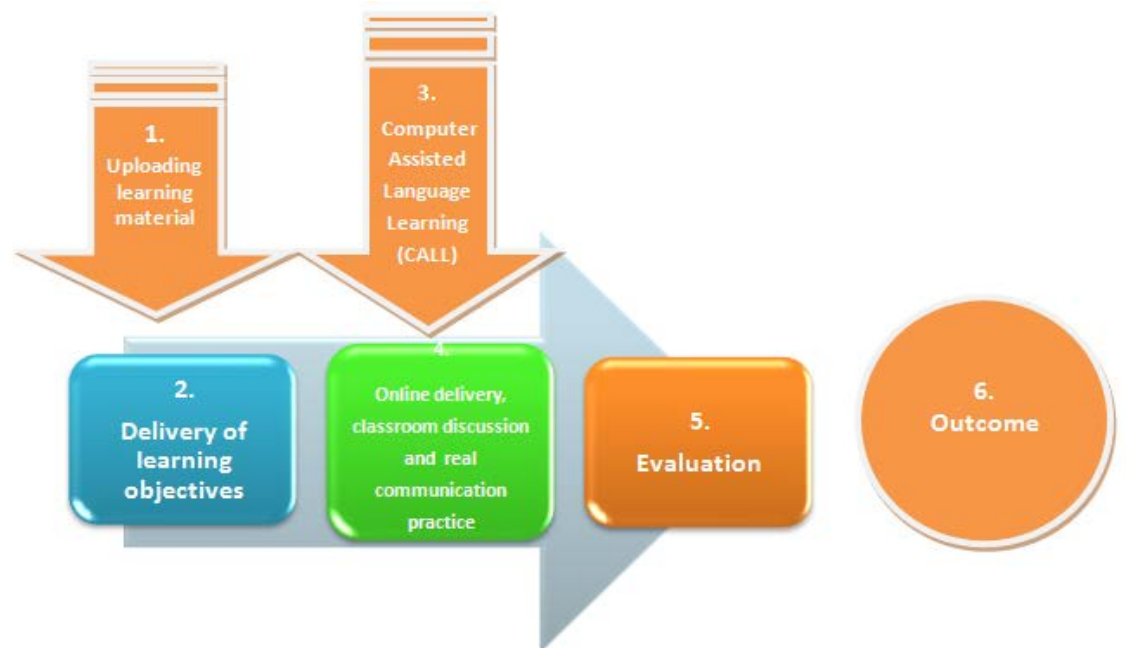

Figure 4. Final Model 
This final CALL-based instruction for learning English speaking skill is chunked into 7 activities: activity 1 for introducing scope and objectives, activity 2 for discussing learning material and unprepared role play, activity 3 for online delivery, activity 4 for classroom discussion, activity 5 for question and answer, simulations, and/or role play, activity 6 for reinforcement, and activity 7 for closing. This model was implemented using a learning management system which was built especially for this research on http://yulidhar1.stkipkusumanegara.ac.id/login.php

This Learning Management System was used as part of the model based on expert assessment on the following aspects: authority with regard to the topic, objectivity, accuracy of the information, currency of a web document, and the ease of operation (usability). An English education expert also provided validation by declaring the eligibility for the CALL-based model for learning speaking English.

The final model was implemented using a Learning Content Management System-based platform which is located on http://yulidhar1.stkipkusumanegara.ac.id /login.php until August 2014. The completion of the research model development coincided with the launch of Google Classroom facilities by Google Apps for Education (GAFE) on August 11, 2014. This new web tools provides additional platform which can be used to implement the CALL-based instruction model. The use of Google Apps for Education Apps in STKIP Kusuma Negara was started in early September in odd semester of academic year of 2014/2015. Speaking English course using CALL-based model was then carried out using Google Classrooms on https://classroom.google.com/c/MTI5NjQwOTZa with class code of 5rsmrpy.

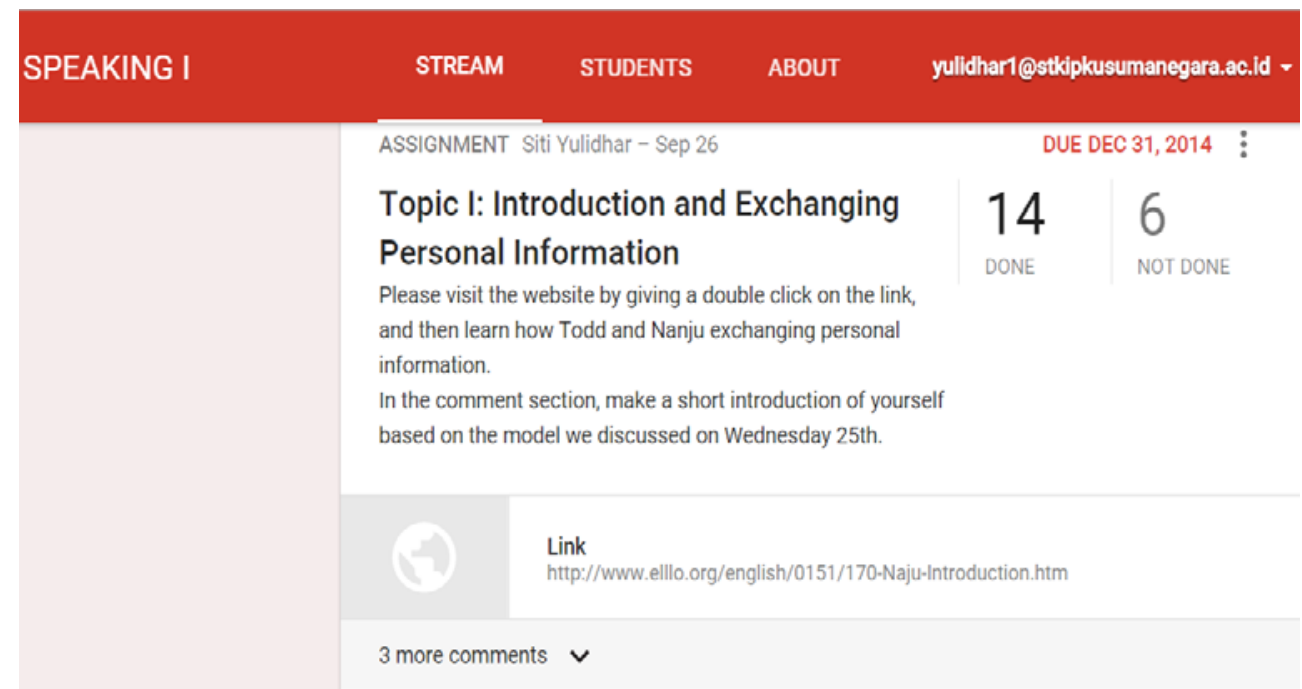

Figure 5. Speaking Class -318104

Besides for Speaking English class, the computer-based instruction model which is a product of this developmental research has been officially adopted by the STKIP Kusuma Negara for all courses in its six study programs. The recommendations for using computer-assisted instruction model as a product of this developmental research was responded by requiring all new students and lecturers to take ICT training and to make use of Google classroom.

Testing of the model effectiveness was conducted in the second semester of the academic year 2013/2014 in class II to see how far the CALL-based instruction 
model can improve speaking skill of students. The students were tested before and after the implementation of the model.

The targeted population of the research was all students of English Education Study Program in STKIP Kusuma Negara. The reachable population was the second semester students of English Education Study Program. A sample of 30 students who were taking Speaking II course was taken using purposive sampling technique.

English speaking tests was conducted before and after the implementation of CALL-based model. The mean of the participants before treatment was 61, and increased to 69 after the use of the model.

Data normality test was performed using the Kolmogorov-Smirnov and Shapiro-Wilk through SPSS 16. The results are presented in Table 2.

Tabel 2. Result of Data Normality Test

Tests of Normality

\begin{tabular}{cccccccc}
\hline & \multicolumn{3}{c}{ Kolmogorov-Smirnov $^{\mathrm{a}}$} & \multicolumn{3}{c}{ Shapiro-Wilk } \\
\cline { 2 - 8 } & Statistic & Df & Sig. & Statistic & df & Sig. \\
\hline After CALL & .227 & 30 & .000 & .909 & 30 & .014 \\
\hline Before CALL & .271 & 30 & .000 & .894 & 30 & .006 \\
\hline
\end{tabular}

a. Lilliefors Significance Correction

The calculation of normality test produces a probability value (sig) .000 and .006 and $.014<\alpha=0.05$. It means that the students' score was from normal distribution. Hypothesis testing was done using a paired samples t-test with SPSS 16 by comparing the data before and after the implementation of CALL-based instruction model with $\alpha=0.05$.

Results of calculation paired samples t-test are presented in Table 3.

Tabel 3. Results of Paired samples t-test Calculation

\begin{tabular}{|c|c|c|c|c|c|c|c|c|}
\hline \multicolumn{9}{|c|}{ Paired Samples Test } \\
\hline & \multicolumn{5}{|c|}{ Paired Differences } & \multirow[b]{3}{*}{$\mathrm{t}$} & \multirow[b]{3}{*}{ df } & \multirow{3}{*}{$\begin{array}{l}\text { Sig. (2- } \\
\text { tailed) }\end{array}$} \\
\hline & \multirow[b]{2}{*}{ Mean } & \multirow{2}{*}{$\begin{array}{c}\text { Std. } \\
\text { Deviation }\end{array}$} & \multirow{2}{*}{$\begin{array}{l}\text { Std. } \\
\text { Error } \\
\text { Mean }\end{array}$} & \multicolumn{2}{|c|}{$\begin{array}{c}\text { 95\% Confidence Interval } \\
\text { of the Difference }\end{array}$} & & & \\
\hline & & & & Lower & Upper & & & \\
\hline $\begin{array}{c}\text { Pair } 1 \text { Before CALL - } \\
\text { After CALL }\end{array}$ & 8.000 & 6.644 & 1.213 & 5.519 & 10.481 & 6.595 & 29 & .000 \\
\hline
\end{tabular}

The calculation produces a probability value (sig) $.000<\alpha=0.05$. Thus, $\mathrm{H}_{0}$ which states that there is no difference between the mean score of students' English speaking skill before and after implementation of the CALL-based model was rejected. The mean scores of English speaking skill before implementation of the model was of 61.00, and 69.00 after the implementation of the model showed that the CALL-based model is better than conventional models used in the earlier speaking course.

As has been expected, the CALL-based model has more advantages compared to conventional learning that has been done so far as described below:

1. The computer-assisted self-learning activities which were carried out before the face-to-face class has proven to develop the students' ability to respond 
automatically to input they received in a communication activity. This is because they already have knowledge of new vocabulary and language expression in accordance with the subject being studied, so in speaking practice students can do it more smoothly. Utilizing CALL, students gain more and longer exposure to the subject matter because of the availability of language models, feedback and explanations that can be accessed by students anytime, anywhere. These findings reinforce that CALL-based model can properly develop the ability to respond to the input that we called automaticity.

2. The Communicative Approach which has been the theoretical foundations for the development of this models of put communicative competence as the main objective. Communicative competence components consisting of grammatical competence, discourse competence, sociolinguistic competence and strategic competence can be developed properly through CALL-based instruction model. By ways of listening and observing firsthand how native speakers of English communicate in a particular context through video / audio which links provided by lecturer through Learning Management System, students can develop their strategic competence, i.e verbal and non-verbal communication strategy as well as developing discourse competency. In addition, extensive learning resources have also allowed students to develop grammatical competence and sociolinguistic competence, i.e. knowledge of the language rules and discourse of social culture. These findings have broadened our knowledge about language learning that Communicative Approach which focuses on the goals and activities of the communication can work well together side by side with the CALL approach which commonly used in language laboratory.

3. The practices of communication in face-to-face class such as question and answer, discussions, simulations and role plays that characterized the Communicative Approach has given students the opportunity to use the competencies they have developed through the CALL-based activity. Through simulations and role plays, students are given a situation and goals, and then they have to develop them into a conversation without much intervention from the lecturer. This kind of activity has been the impetus for students to communicate. These findings reinforce opinion that the non-communicatice activities would not be the impetus for students to communicate, and vice versa.

4. Self-directed learning can help students to become autonomous learners. This can be seen from the students' responses in the form of questions and comments on chat facility in Google classroom. Links to learning resources given in the virtual classroom were studied and responded positively. Utilizing this hypermedia technology, students can also access other relevant materials as usually a webpage provides some links associated with the content they contain. This finding indicates that students with interest and intrinsic motivation showed a greater level of comfort, and showed deeper engagement when performing their tasks.

5. CALL-based instruction model is also developing other language skills although the ultimate goal is to improve English speaking skill. It can be seen from the students' work recorded in the system. Results of this study as well disprove the common assumption stated that learning using web applications is only suitable for teaching writing and reading. The evidence suggests that in addition to improvement of students 'speaking skill this model also had a positive impact on 
the development of students' writing skill. This is in line with the principle that language learning should be integrated and mutually supportive. As a language is not a separate part, the learning in the classroom must integrate the four language skills.

6. From teacher's point of view, the CALL-based instruction model has facilitated the management of the learning process and made the organization of teaching materials more easily. Teachers can take advantage of the management system for delivering learning materials to students and direct students to the learning resources that can be accessed anytime and anywhere, without being limited by the format of the document. They can also communicate with students using facilities available in the system. In addition, the ability to store information in a Learning Management System has allowed teachers to do evaluation process efficiently. These findings support the idea that CALL-based instruction model provides benefits for teachers in terms of evaluation.

However, in addition to the advantages mentioned above, CALL-based model is not independent from its shortcomings. There are also major factors that become a challenge for the CALL-based model. Users must meet a certain level of ability to use this model. It also requires adequate facilities and infrastructure so that this model can be implemented properly. Classroom activities such as discussions, simulations and role-plays done in pairs or groups need large space to accommodate. In small classrooms, activity is limited and can only be done through a demonstration in front of the class, and role-play or debriefing should be conducted from each seat.

Students must have the knowledge and skills to access and navigate the web in order to study the material provided.The lack of this capability can lead to delayed classroom tasks. Lecturer had to extend the time limit so that all students have the opportunity to submit their work. Due to this reason, the student assignment recorded in the system should not be used as the main component of evaluation.

Web application used as a Learning Management System for CALL-based instruction model should have features that allow the implementation of a complete learning process. Based on these considerations, it is required an in-depth study and considerable support in terms of funding and implementation so that this model can be implemented effectively.

\section{CONCLUSION}

From the research results, it can be concluded that Computer Assisted Language Learning-based instruction model which covers self directed learning and then followed by in-site activities could be an instruction model to improve students' English speaking skill at the English Education Study Program of STKIP Kusuma Negara.

This CALL-based instruction model is effective to improve students' English speaking skill shown by the improvement of their means score from 61 before the implementation of the model to 69 .

The conclusion is based on the all steps of development and the results of evaluation of the model as follow: 
1. The results of needs analysis based on the component of learning necessities, lacks and wants are:

a. Students looked at the importance of speaking English fluently and accurately for English teachers/pre-service teachers.

b. Students felt the lack of their ability in selecting appropriate vocabulary or phrases in context, and of communications strategies.

c. Students expect an increase in the frequency of conversation practice, learning materials and learning resources enrichment, and conversation models by native speakers of English.

Meanwhile, the results of the needs analysis for lecturers recommended to multiply practices of role playing and discussions in the classroom consider that speaking English is a skill, not only a knowledge. It is also recommended to use websites to support the enrichment of learning resources and learning materials.

2. Observation on the learning process in the Speaking classrooms in English Education Study Program STKIP Kusuma State showed: a) classroom conversation is still more dominated by lecturers than students, b) text books are more widely used than the multimedia, c) lecturers use presentation methods by providing specific topics to students and then have the students prepare and present the topic, d) students seem more interested in the daily life topics, and in the use of technology in the classroom.

3. The CALL-based instruction model suitable for students of English Education in STKIP Kusuma Negara is the model that facilitates them to be able to do selfdirected learning before class, and then followed by discussions, simulations, or role play in face-to-face class.

4. Statement of the feasibility of the model being developed is obtained through the experts judgement with the following results:

a. ICT expert stated that the website of STKIP Kusuma Negara which is located on http://yulidhar.stkipkusumanegara.ac.id is viable and good to be used as part of the CALL-based instruction model.

b. English education expert stated the feasibility of this CALL-based instruction model for learning English speaking skill.

The final CALL-based instruction model is proven to be effective in improving the students' speaking skill in English Education Study Program of STKIP Kusuma Negara Jakarta. This model increases the mean scores of students from 61 before the implementation to 69 after the implementation of the model. Testing of research hypothesis which states that there are differences between the mean score of students' speaking skill after and before utilizing CALL-based model generates a probability value (sig) $.000<\alpha=0.05$. This means there is significant difference in the mean scores of students' English speaking skill before and after the implementation of CALL-based instruction model.

\section{REFERENCES}

Bates, A.W. \& Gary Poole. (2003). Effective Teaching with Technology in Higher Education: Foundations for Success. San Francisco: Jossey-Bass. 
Brown, H. Douglas. (2007). Teaching by Principles: An Interactive Approach to Language Pedagogy. New York: Pearson Education.

Dick, Walter, Lou Carey \& James O. Carey. (2005). The Systematic Design of Instruction, Sixth Edition. Boston: Pearson Education.

Dudeney, Gavin \& Nicky Hockly. (2007). How to Teach English with Technology. Edinburgh: Pearson Education.

Gall, Meredith D., Joyce P. Gall, \& Walter R. Borg. (2003). Educational Research: An Introduction. $7^{\text {th }}$ ed. Boston: Pearson Education.

Harmer, Jeremy. (2001). The Practice in Language Teaching. $3^{\text {rd }}$ ed. UK: Pearson Education.

Hartoyo. (2008). Individual Differences in Computer-Assisted Language Learning (CALL). Semarang: Pelita Insani.

Harunasari, Siti Yulidhar. (2011). Peningkatan Keterampilan Berbicara Bahasa Inggris Melalui Penerapan Teknik Role Play, Penelitian Tindakan Pada Mahasiswa Jurusan Pendidikan Bahasa Inggris Sekolah Tinggi keguruan dan Ilmu Pendidikan Kusuma Negara Jakarta. Master Thesis. Postgraduate Study Program, State University of Jakarta.

Hubbard, Peter et.al. (2013). A Training Course for TEFL. Oxford: Oxford University Press.

Joyce, Bruce, Marsha Weil and Emily Calhoun. (2000). Models of Teaching. USA: Pearson Education.

Lee, William W dan Diana L. Owens. (2004). Multimedia-Based Instructional Design. San Francisco: Pfeiffer.

Nation ISP \& John Macalister. (2010). Language Curriculum Design. New York: Routledge.

Nation, ISP \& Jonathan Newton. (2009). Teaching ESL/EFL Listening and Speaking. New York: Routledge.

Richard-Amato, Patricia A. (2010). Making It Happen, From Interactive to Participatory Language Teaching: Evolving Theory and Practice, Fourth edition. New York: Pearson Education.

Richards, Jack C. (2005). Curriculum Development in Language Teaching $5^{\text {th }}$ ed. Cambridge: Cambridge University Press.

Richey, Rita C., James D. Klein \& Monica W. Tracey. (2011). The Instructional Design Knowledge Base: Theory, Research, and Practice. New York: Routledge. 
Sugiyono. (2010). Metode Penelitian Pendidikan: Pendekatan Kuantitatif, Kualitatif, dan $R \& D$. Bandung: Alfabeta.

Swe Khine, Mynt (ed.). (2006). Teaching With Technology: Strategies for Engaging Learners. Jurong: Prentice Hall.

Thornbury, Scott. (2008). How to Teach Speaking. UK: Pearson Education.

Tomlinson, Brian, (2007). Developing Materials for Language Teaching (Wiltshire: Cromwell Press. 
International Journal of Language Education and Culture Review 